\title{
КЛАСИФІКАЦІЯ УРАЖЕНЬ ЛЕГЕНЬ ПРИ COVID-19 НА ОСНОВI ТЕКСТУРНИХ ОЗНАК ТА ЗГОРТКОВОЇ НЕЙРОННОЇ МЕРЕЖІ
}

\author{
Давидько О.Б. ${ }^{1}$, аспірант \\ o.davydko@kpi.ua \\ Ладік A.O. ${ }^{1}$, бакалавр \\ artur.ladik01@gmail.com \\ Максименко В.Б. ${ }^{1}$, д.м.Н., проф. \\ maksymenko.vitaliy@gmail.com \\ Линник М. I. ${ }^{2}$, д.м.н., п.н.с \\ linnyk@ifp.kiev.ua \\ Павлов О.В. ${ }^{1}$, К.Т.Н., ст.п. \\ cheshirelk@gmail.com \\ Настенко . ${ }^{1}{ }^{1}$, к.Т.н., д.б.н., проф. \\ nastenko.e@gmail.com
}

\author{
${ }^{1}$ Національний технічний університет України «Київський \\ політехнічний інститут імені Ігоря Сікорського» \\ м. Київ, Україна \\ ${ }^{2} Д У$ «Національний інститут фтизіатрії і пульмонології \\ ім. Ф.Г. Яновського НАМН України» \\ м. Київ, Україна
}

Peферат - Проблематика. Визначення структури ураження легеневої тканини хворих на COVID-19 по типовим ознакам «матове скло», «бруківка», «консолідація» $є$ важливою складовою обгрунтування діагнозу та лікувальних заходів на поточний момент терапії пацієнта. Найбільш поширеним засобом визначення стадії та типу ураження дихальних шляхів $\epsilon$ аналіз рентген зображень та комп'ютерної томографії (КТ). Оскільки особливістю вірусної пневмонії SARS-CoV-2 є швидкий перехід від легких стадій до важких з розвитком цитокинового шторму і розповсюдження вірусу в артеріальний кровотік, то надійний та швидкий аналіз КТ зображень легень пацієнта $є$ запорукою прийняття своєчасних лікувальних заходів. В даній роботі розглядаються можливості застосування засобів штучного інтелекту для вирішення задачі класифікації уражень легень при захворюванні COVID-19.

Mema. Метою роботи є створення класифікаційної системи типу уражень легень при COVID-19 по типовим ознакам «матове скло», «бруківка», «консолідація» на основі згорткової нейронної мережі CNN та текстурних ознак, джерелом яких $є$ матриці суміжності GLCM при різних значеннях кутів напрямку аналізу.

Методика реалізаиії. Оскільки основою відмінностей різних типів ураження легеневої тканини на КТ зображеннях $\epsilon$ відмінності у їх текстурних характеристиках, то в основу простору ознак класифікаційної системи закладемо елементи гістограм на основі матриць суміжності областей інтересу КТ зображень легень. У зв’язку з високими якостями перетворення простору ознак до потреб задач класифікації згортковими шарами мережі, засобом побудови класифікатора пропонується застосувати згорткову нейронну мережу. Для навчання системи ДУ “«Національний інститут фтизіатрії і пульмонології ім. Ф.Г. Яновського НАМН України» було надано 794 КТ зрізів від 20 пацієнтів із масками зображень, на яких виділені 4714 зони інтересу з означеними типами уражень легень. Була побудована модель семишарової згорткової нейронної мережі: із чотирма згортковими шарами, після перших трьох з яких йдуть агрегувальні шари. На вхід згорткової нейронної мережі одночасно подаються текстурні ознаки двох GLCM, які були отримані із сегментованих КТ зображень під різними кутами. В якості функції втрат була використана NLLLOSS. Шар активації Softmax визначає результат задачі класифікації.

Результати дослідження. Побудована згорткова нейронна мережа на тестовій вибірці з 472 зображень має загальну точність класифікації у 83\%, на класі «матове скло» - 90,1\%, «бруківки»- 70,5\%, «консолідація» - 54,2\% та на робочій вибірці з 4714 ROI зображень має загальну точність у 98\%, на класі «матове скло» - 98,6\%, «бруківка» - 96,8\%, «консолідація» - 95,4\% Висновки. В роботі одержано модель з високою ефективністю класифікації типу уражень легень при COVID-19. Класифікатор побудовано на основі згорткової нейронної мережі та ознак текстури, джерелом яких є матриці суміжності областей інтересу КТ зображень легень.

Ключові слова - GLCM, матриия суміжності, область інтересу, комп'ютерна томографія, COVID-19, згорткова нейронна мережа, ураження легень, матове скло, бруківка, консолідація. 


\section{I. ВСТУП}

«SARS-CoV2» - новий штам коронавірусів, який викликає важке респіраторне захворювання коронавірусної хвороби (COVID-19), чия висока заразність робить нагальною потребу якомога швидшого діагностування хвороби, зокрема тому, що вже до кінця першого тижня захворювання може прогресувати до пневмонії, дихальної недостатності i смерті. На сьогоднішній день найбільш поширеним способом діагностики хвороби $\epsilon$ полімеразна ланцюгова реакція (ПЛР). Проте ПЛР тести дають лише до 60\% точності [1], а на отримання результати йде до кількох днів.

Однією 3 альтернатив визначення захворювання людини на COVID-19 через ураження дихальних шляхів $€$ аналіз зображень комп'ютерної томографії (КТ) легень. Щодо точності діагностики та визначення структури уражень при аналізі зображень КТ людиною, вона критично залежить від кваліфікації лікаря. А при наявних наднавантаженнях лікарів на ранніх стадіях легко пропустити малі та слабко інфіковані області зображень. У зв'язку 3 цим, для пришвидшення та збільшення точності постановки діагнозу в медицині все частіше використовуються технології глибинного навчання, об'єктивізації результатів аналізу має служити застосування засобів штучного інтелекту. Комп'ютерний аналіз може визначати ознаки вірусної пневмонії, викликаної COVID-19 навіть на ранніх стадіях хвороби, що є важливим фактором для запровадження лікувальних заходів, оскільки особливістю вірусної пневмонії SARS-CoV-2 $\epsilon$ швидкий перехід від легких стадій до важких з розвитком цитокінового шторму і розповсюдженням інфекції в артеріальний кровотік.

Більшість існуючих робіт ставлять за мету класифікувати наявність COVID-19 на основі КТ зображень або рентгену грудної клітини, маючи на виході лише два класи: позитивний результат на коронавірус, або негативний. 3 цією метою використовують різні методи. Наприклад у роботі [2] було використано прості згорткові мережі i завчасно натреновану модифіковану модель AlexNet для експериментів 3 наборами даних рентгенівських знімків $\mathrm{i}$ зображень комп'ютерної томографії, досягнувши точності 98\% і 94,1\% для двох моделей нейронних мереж. $\mathrm{y}$ [3] використали три види згорткових нейронних мереж (ResNet50, InceptionV3 i InceptionResNetV2), серед яких ResNet50 мав найкращий ефект класифікації, a точність InceptionV3 i InceptionResNetV2 склала 97\% і 87\% відповідно. У роботі [4] було розроблено класифікаційну мережу для діагностики COVID із сімома різними модулями. Результати показали, що VGG19 i DenseNet мають схожі хороші характеристики, а показники f1 для розрізнення норми і COVID-19 складають 0,89 і 0,91 відповідно. У роботі [5] було порівняно деякі архітектури глибинних згорткових мереж i було 3'ясовано, що точно налаштовані версії Resnet50, MobileNet_V2 i Inception_Resnet_V2 мають досить задовільну продуктивність і можуть досягати рівня точності більшого за 96\%.

Однак, оскільки на ранніх стадіях COVID-19 може проявляти симптоми пневмонії, які присутні і за наявності інших збудників хвороби, алгоритми глибинного навчання коректніше використовувати для сегментації областей ураження пневмонії, на основі аналізу яких лікар в подальшому виносить рішення.

Подібний метод використано у роботі [6], в якій пропонується трьох етапний підхід глибинного навчання, за якого згорткова нейронна мережа спершу використовується для знаходження наявності пневмонії, за яким слідує визначення типу пневмонії i ㄲi відображення на рентгенівському знімку.

У більшості наведених вище роботах область інтересу (ROI) для навчання мережі розмічена лікарями-рентгенологами, що позначають на зображеннях ділянки, яким необхідно присвятити увагу. Діагноз (тип ураження) ставиться відповідно до текстури та морфології вмісту області інтересу. При реалізації у Замовника система повинна містити підсистему сегментації області уражень та підсистему класифікації типу уражень легеневої 
тканини. Нижче розглядається побудова підсистеми класифікації типу уражень легень при COVID-19 на основі KT зображень та застосування згорткової нейронної мережі $\mathrm{CNN}$.

Більшість схем аналізу КТ зображень легень застосовують на вході CNN ознакиінтенсивності шкали пікселей відтінків сірого чи шкали Хаунсфілда вхідного зображення, при цьому класифікуючі здібності мережі обмежені властивостями розташування та наявністю чи відсутністю пікселів з тими, чи іншими відтінками у ROI. Альтернативою для зображень, де в основі класифікації лежать характеристики текстури є обробка мережею безпосередньо частотних ознак - елементів гістограм матриці суміжності GLCM, що дозволяють аналізувати просторові відношення відтінків пікселів. Даний підхід не $\epsilon$ широко розповсюдженим у зв'язку з тим, що GLCM матриці наряду 3 корисною інформацією містить величезну кількість дублюючих ознак та зайвої інформації, що при невдалому налаштуванні мережі призводить до падіння якості класифікації. У роботі [7] наведено приклад налаштування системи такого типу та відмічено переваги та недоліки даного підходу. Проте зважаючи на принциповий факт того, що відмінності у класах типу уражень легень при COVID-19: «матове скло», «бруківка», «консолідація» (рис.1,2,3) полягають саме у відмінностях текстури зображень ROI, в роботі для побудови системи класифікації пропонується застосувати згорткову нейронну мережу CNN та ряд гістограм на основі матриць суміжності GLCM в якості джерела ознак текстури. Матриці GLCM формуються під різними кутами із оригінальної вибірки КТ зображень 20 пацієнтів.

\section{II. ПОСТАНОВКА ЗАДАЧІ}

Метою роботи $\epsilon$ розробка системи класифікації типових уражень легень при COVID-19: «матове скло», «бруківка», «консолідація» на основі згорткової нейронної мережі CNN та гістограм матриць суміжності GLCM областей інтересу КТ зображень в якості джерел ознак текстури.

\section{III. ОПИС КТ ЗОБРАЖЕНЬ}

При захворюванні на COVID-19 у пацієнта по-різному виглядає структура легень, в залежності від типу ураження. На ранній стадії ураження легень відносно локалізоване і в основному проявляється у вигляді запальної інфільтрації, розташованою периферично переважно в нижніх долях обох легень або рідше в одній легені як симптоми «матового скла» із судинною дилатацією [8].

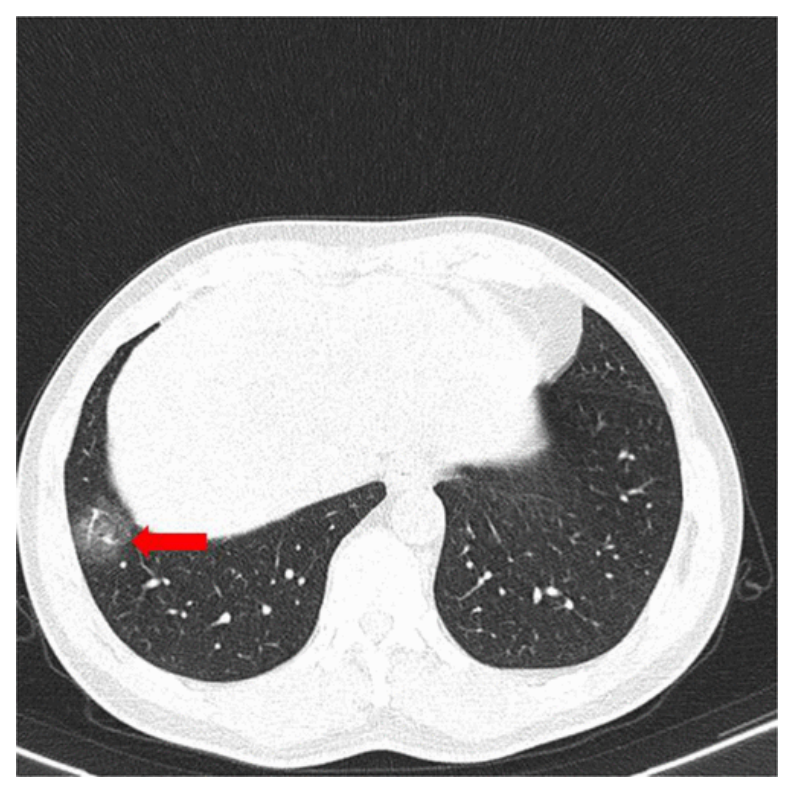

Рис. 1 Спостерігається синдром «матового скла» в базальному сегменті правої нижньої долі і розширення судин всередині ураження [8].

На прогресуючій стадії КТ показує в основному збільшений діапазон чистого «матового скла», ураження декількох долей, часто має місце потовщення міждольової перегородки та очевидний симптом «бруківки» [8].

На пізній стадії на КТ зображеннях спостерігаються дифузні ураження в обох легенях в основному у вигляді консолідованих уражень і матового скла, що оточують консолідовані ураження [8]. 


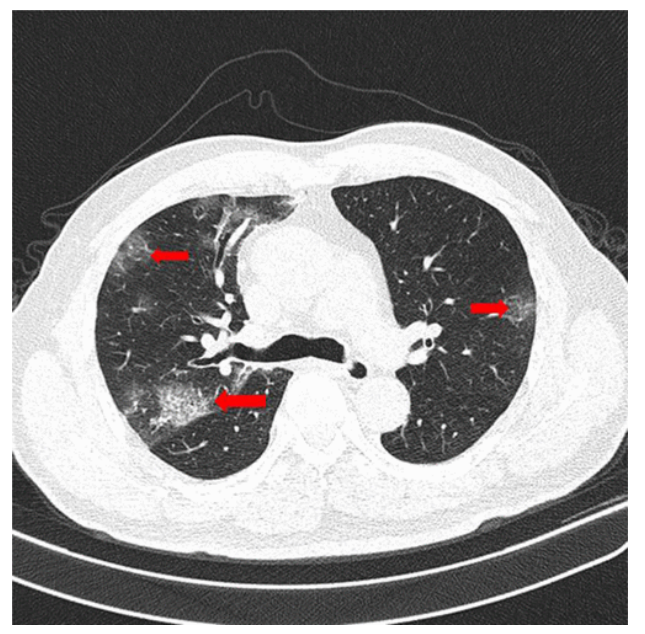

Рис.2 Спостерігаються множинні помутніння у вигляді матового скла в обох легенях, потовщення міждольової перегородки, візерунок симптому «бруківки» [8].

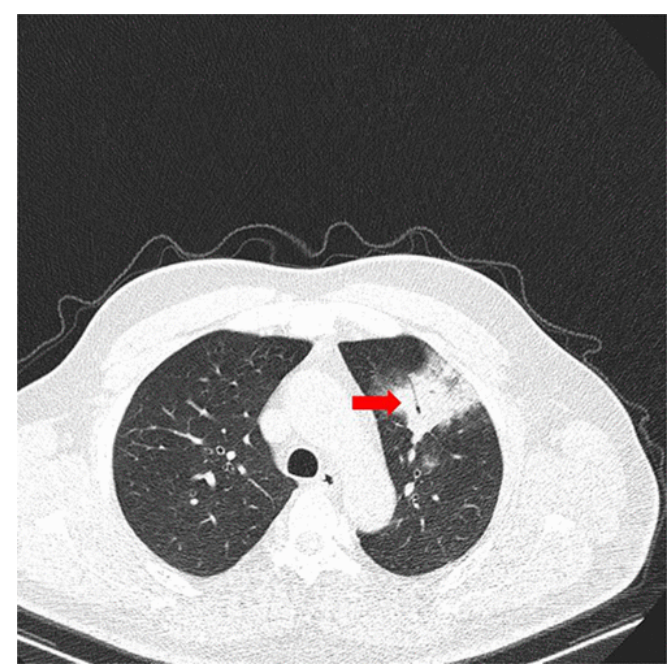

Рис.3 Спостерігається плямиста консолідація у лівій верхній долі, частково консолідовану легеневу тканину, матове скло по краях і повітряну бронхограму в центрі ураження [8].

\section{IV. ОТРИМАННЯ ТЕКСТУРНИХ ОЗНАК}

Легенева маска створюється для виключення впливу інших тканин на результат аналізу моделі. Першим завданням є сегментація області інтересу на основі відповідної маски з кожного зрізу. Початкові необроблені 2D зображення КТ зрізів підготовлені в шкалі одиниць Хаунсфілда (HU). 3 метою зменшення дублюючих частотних ознак

шкала відтінків зменшується до діапазона $[0,255]$ та отримані області інтересу проходять через диференційне перетворення першого порядку 3 метою одержання матриць суміжності, незалежних від зміщення характеристик конкретного обладнання.

Зміст використання матриць суміжності GLCM полягає у розгляді статистик другого порядку: досліджуються частоти присутності пари пікселів певних відтінків в певних просторових відношеннях один до одного. Матриці GLCM містять всі поєднання частот інтенсивності пар пікселів у зображенні, після чого кожне значення частоти записується у відповідний елемент матриці. I3 2D зображення можна отримати 4 різні GLCM матриці, використовуючи 4 напрямки аналізу під кутом $\theta$ : $\left(0 \circ, 45^{\circ}, 90^{\circ}, 135^{\circ}\right)$. У даній роботі різні текстурні ознаки отримуються 3 однакових областей інтересу, шляхом отримання текстурних ознак за допомогою двох GLCM матриць: 3 напрямом 0 ॰ та напрямом $45^{\circ}$.

Обом матрицям задаються значення напрямку i кроку відстані, після чого у матрицю записуються частоти інтенсивності пар пікселів у зображенні. Для отримання відносних частот нормалізуємо елементи матриці шляхом ділення всіх значень елементів матриці на загальну їх кількість.

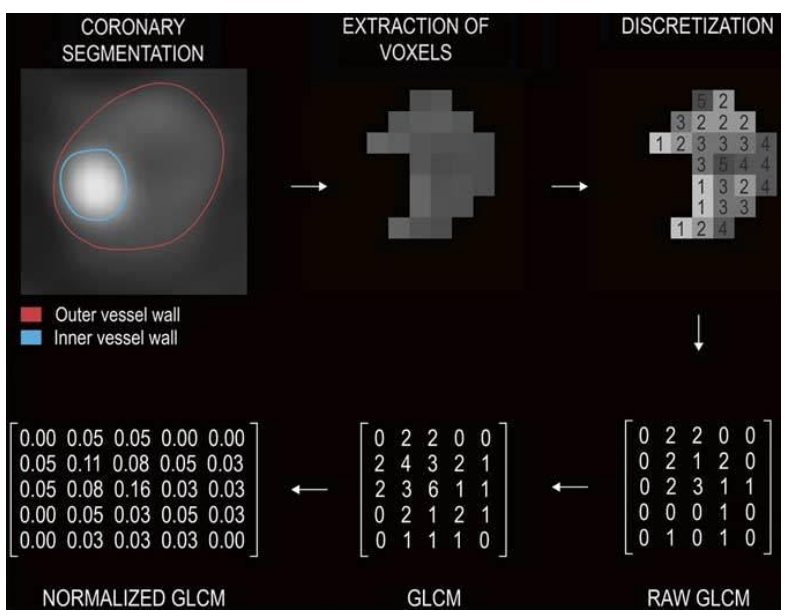

Рис.4 Приклад алгоритму розрахунку матриці GLCM при отриманні текстурних ознак 3 сегментованого КТ зображення коронарної артерії (відстань 1, напрямок 0॰) [3] 


\section{V. КЛАСИФІКАЦІЯ}

Для навчання системи використано 794 КT- зрізів (4714 ROI зображень) від 20 пацієнтів із підтвердженою хворобою на COVID-19 на різних стадіях розвитку.

Розподіл ROI зображень по класам виглядає наступним чином:

\section{Таблиия 1. Розподіл класів даних КТ зображень}

\begin{tabular}{|c|c|c|c|}
\hline $\begin{array}{c}\text { Тип } \\
\text { текстури } \\
\text { легень }\end{array}$ & $\begin{array}{c}\text { Загальний } \\
\text { розподіл } \\
\text { класів }\end{array}$ & $\begin{array}{c}\text { Розподіл } \\
\text { класів у } \\
\text { навчальній } \\
\text { вибірці }\end{array}$ & $\begin{array}{c}\text { Розподіл } \\
\text { класів у } \\
\text { тестовій } \\
\text { вибірці }\end{array}$ \\
\hline $\begin{array}{c}\text { Симптом } \\
\text { «матового } \\
\text { скла» }\end{array}$ & 3563 & 3200 & 363 \\
\hline $\begin{array}{c}\text { Симптом } \\
\text { «руківки» }\end{array}$ & 635 & 574 & 61 \\
\hline Консолідація & 516 & 468 & 48 \\
\hline
\end{tabular}

Для забезпечення більш ефективної і надійної процедури навчання мережі застосовано штучне усунення розбалансованості розподілу класів, для цього GLCM матриці класів 3 меншою кількістю зразків у навчальній вибірці було випадковим чином продубльовано В результаті розподіл зразків по класам маємо, як на рисунку 5. Набір даних був випадковим чином розбитий на навчальну та тестову вибірки на 90\% та 10\% від початкового набору відповідно таким чином, щоб збереглися оригінальні пропорції розподілу класів. Нейронна мережа в роботі сконстуйована як композиція двох ідентичних згорткових нейронних мереж, кожна 3 яких формує у процесі навчання стиснені вектори ознак.

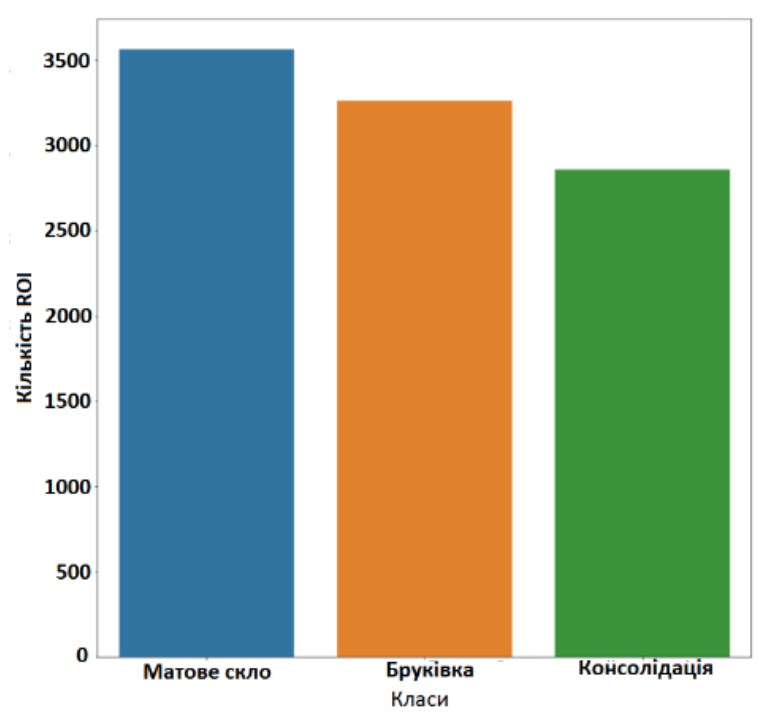

Рис.5 Графік загального розподілу класів КТ зображень після штучного балансування

Після згорткових мереж було використано повнозв'язну мережу, що приймає на вхід створені попередніми мережами ознаки $\mathrm{i}$ дає на виході ймовірності належності об'єкту до класу за допомогою функції Softmax. Згорткові мережі складаються з чотирьох згорткових шарів (convolutional layers), за першими трьома 3 яких йдуть агрегувальні шари (pooling layers) MaxPool iз розміром вікна $2 \times 2$. Всі згорткові шари мережі використовують ReLU як функцію активації. Повну структуру мережі, включаючи повнозв'язну частину зображено на рисунку 6:

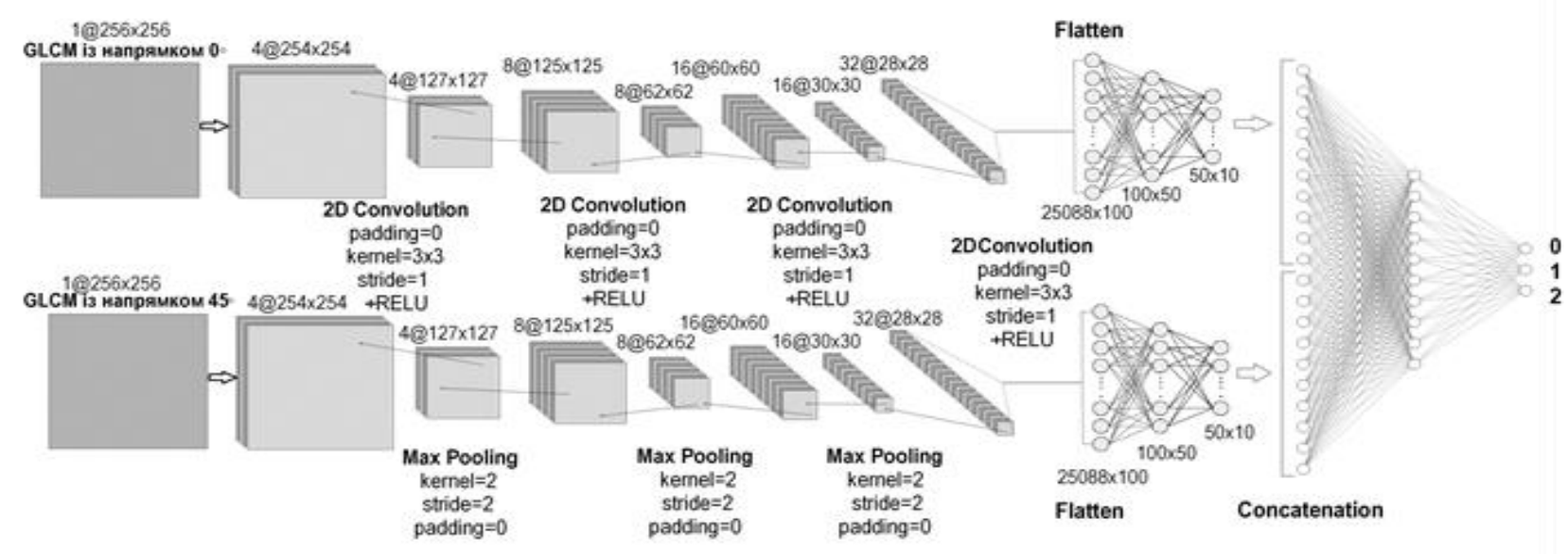

Рис.6 Архітектура запропонованої композитної моделі 
Таким чином, створена мережа приймає на вхід дві GLCM, створені із різними параметрами, а на виході дає ймовірність приналежності вхідного об'єкту до класів. В результаті обирається клас, для якого ймовірність приналежності $є$ найбільшою. В якості критерію якості тренування було обрано функцію cross-entropy loss, яка широко застосовується у задачах багатокласової класифікації [9].

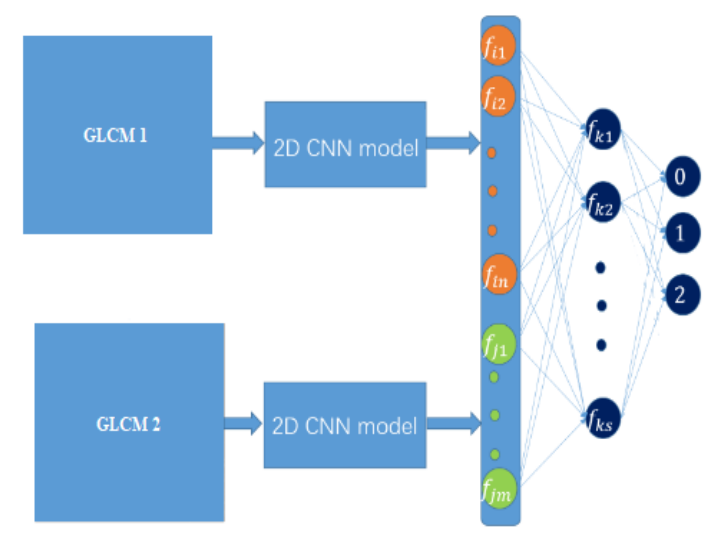

Рис.7 Архітектура запропонованої моделі із двома входами до CNN моделі, на які подаються текстурні ознаки областей інтересу у вигляді Рис.8 GLCM матриць

\section{VI. РЕЗУЛЬТАТИ ДОСЛІДЖЕННЯ}

Результати класифікації симптомів патології легень при COVID-19 за допомогою загорткової нейронної мережі та текстурних ознак областей інтересу КТ зображень, дозволяють стверджувати про доцільність використання технології класифікації уражень легень при COVID19 за допомогою текстурних ознак їх КТзображень, отриманих за допомогою двох GLCM матриць 3 кутом 0 ॰ та 45。.

\section{Таблиия 2. Результати класифікації}

\begin{tabular}{|l|c|c|c|c|}
\hline & $\begin{array}{c}\text { Точність } \\
\text { загальна }\end{array}$ & $\begin{array}{c}\text { Точність } \\
\text { класу 1 }\end{array}$ & $\begin{array}{c}\text { Точність } \\
\text { класу 2 }\end{array}$ & $\begin{array}{c}\text { Точність } \\
\text { класу 3 }\end{array}$ \\
\hline Навчання & $99.67 \%$ & $99.6 \%$ & $99.6 \%$ & $99.7 \%$ \\
\hline $\begin{array}{l}\text { Тест } \\
\text { вибірка }\end{array}$ & $83 \%$ & $90.1 \%$ & $70.5 \%$ & $54.2 \%$ \\
\hline $\begin{array}{l}\text { Робоча } \\
\text { вибірка }\end{array}$ & $98 \%$ & $98,6 \%$ & $96,8 \%$ & $95,4 \%$ \\
\hline
\end{tabular}

В результаті на отриманій класифікаційній моделі було одержано загальну точність у $83 \%$ на 472 тестових зображеннях із точністю для класу симптом «матового скла» - 90,1\%, симптом «бруківки» - 70,5\%, «консолідація» $54,2 \%$.
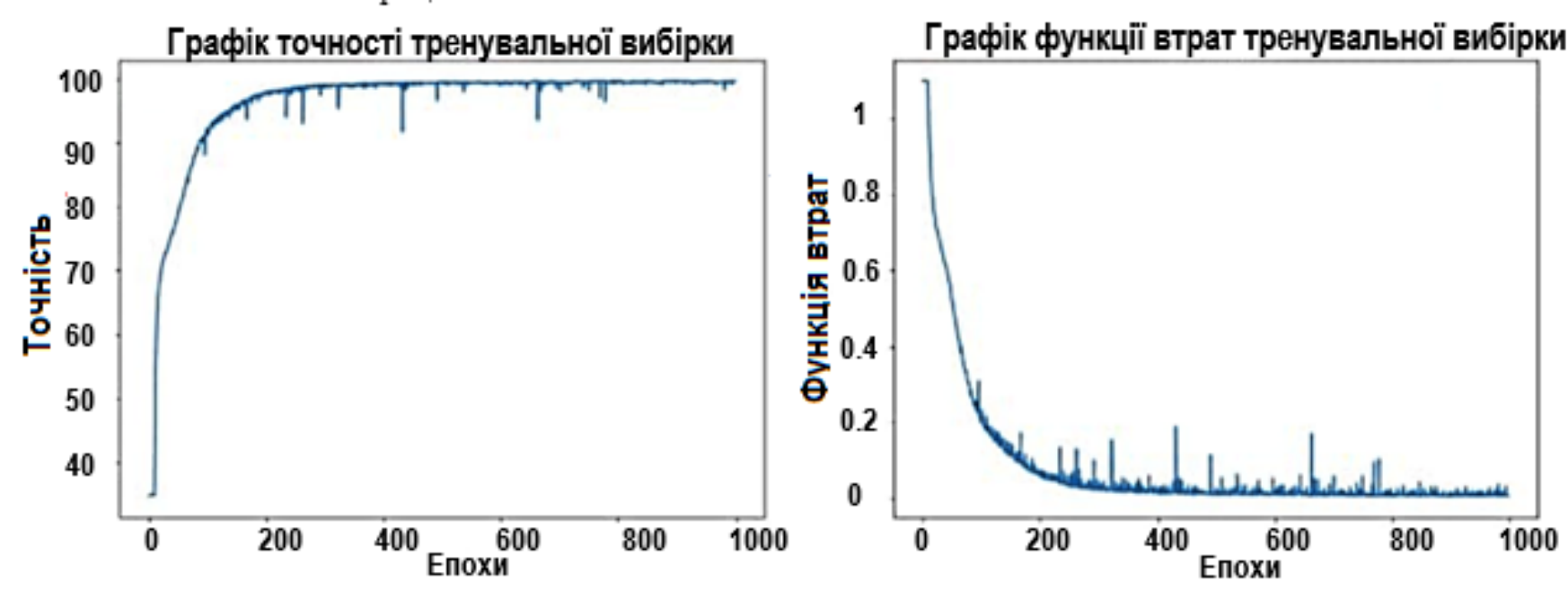

Рис. 8. Графік точності(зліва) та функції втрат(справа) 


\section{VII. ВИСНОВКИ}

В роботі розроблено класифікатор типу уражень легень при COVID-19 на основі згорткової нейронної мережі та частотних ознак текстури сформованих на основі матриць суміжності відтінків сірого GLCM 3 кутом $0 \circ$ та $45^{\circ}$. Аналіз близьких по змісту робіт [10,11] (дані табл. 3) дозволяе стверджувати про конкурентоздатність одержаних в роботі моделей.

\section{Таблиия 3 Порівняння результатів}

\begin{tabular}{|c|c|}
\hline Модель & $\begin{array}{c}\text { Загальна } \\
\text { точність }\end{array}$ \\
\hline $\begin{array}{c}\text { Запропонована } \\
\text { модель }\end{array}$ & $83 \%$ \\
\hline ResNet-101 [10] & $79,87 \%$ \\
\hline ResNet-34 [10] & $81,85 \%$ \\
\hline AlexNet [10] & $75,76 \%$ \\
\hline VGG16 [10] & $88,34 \%$ \\
\hline ANN classifier[11] & $82 \%$ \\
\hline
\end{tabular}

\section{Отримані результати демонструють} ефективність та перспективність застосування класифікаційної моделі типів ураження легенів при COVID-19 на основі згорткової нейронної мережі $\mathrm{CNN}$ та гістограм матриць суміжності відтінків сірого GLCM в якості джерел ознак текстури на вході мережі. Наступні дослідження буде спрямовано на збільшення кількості застосованих різноманітних текстурних ознак та на удосконалення структурних властивостей класифікаційних моделей.

Версія системи для лікаря має включати підсистему сегментації області уражень легеневої тканини, підсистему класифікації областей ураження легень по типу «матове скло», «бруківка», «консолідація», оцінку об'єму уражень по кожному типу та прогноз прогресу захворювання на найближчі строки.

\section{ПЕРЕЛІК ПОСИЛАНЬ}

[1] Ai T, Yang Z, Hou H, Zhan C, Chen C, Lv W, Tao Q, Sun Z, Xia L. Correlation of Chest CT and RT-PCR Testing for Coronavirus Disease 2019 (COVID-19) in China: A Report of
1014 Cases. Radiology. 2020 Aug;296(2):E32-E40. doi: 10.1148/radiol.2020200642. Epub 2020 Feb 26. PMID: 32101510 ; PMCID: PMC7233399.

[2] Krizhevsky A, Sutskever I, Hinton GE. Imagenet classification with deep convolutional neural networks. In: Proceedings of the 25th international conference on neural information processing systems. 2012; 1. p. 1097-1105.

[3] Narin A, Ceren K, Ziynet P. Automatic detection of coronavirus disease (covid-19) using X-ray images and deep convolutional neural networks. arXiv:2003.10849; 2020.

[4] Hemdan, E.E.D.; Shouman, M.A.; Karar, M.E. Covidxnet: A framework of deep learning classifiers to diagnose covid-19 in X-rayimages.arXiv2020, arXiv:2003.11055

[5], Asnaoui K, Chawki Y, Idri A, et al. Automated methods for detection and classification pneumonia based on X-ray images using deep learning. 2020, arXiv:2003.14363.

[6] Brunese L, Mercaldo $F$, Reginelli A, Santone A. Explainable Deep Learning for Pulmonary Disease and Coronavirus COVID-19 Detection from X-rays. Comput Methods Programs Biomed. 2020 Nov;196:105608. doi: 10.1016/j.cmpb.2020.105608. Epub 2020 Jun 20. PMID: 32599338; PMCID: PMC7831868.

[7] $\mathrm{Hu}$, Yifan and $Y$. Zheng. "A GLCM Embedded CNN Strategy for Computer-aided Diagnosis in Intracerebral Hemorrhage." ArXiv abs/1906.02040 (2019): n. pag.

[8] Dai W, Zhang H, Yu J, et al. CT Imaging and Differential Diagnosis of COVID-19. Canadian Association of Radiologists Journal. 2020;71(2):195-200. doi:10.1177/0846537120913033

[9] Nasr, G.E. \& Badr, E. \& Joun, C.. (2002). Cross Entropy Error Function in Neural Networks: Forecasting Gasoline Demand.. 381-384.

[10] Irmak, E. COVID-19 disease severity assessment using CNN model. IET Image Process. 2021; 15: 1814- 1824. https://doi.org/10.1049/ipr2.12153

[11] Carvalho, A.R., et al.: COVID-19 chest computed tomography to stratify severity and disease extension by artificial neural network computer-aided diagnosis. Front. Med. 7(12), 1-11 (2020)

\section{REFERENCES}

[1] Ai T, Yang Z, Hou H, Zhan C, Chen C, Lv W, Tao Q, Sun Z, Xia L. Correlation of Chest CT and RT-PCR Testing for Coronavirus Disease 2019 (COVID-19) in China: A Report of 1014 Cases. Radiology. 2020 Aug;296(2):E32-E40. doi: 10.1148/radiol.2020200642. Epub 2020 Feb 26. PMID: 32101510 ; PMCID: PMC7233399.

[2] Krizhevsky A, Sutskever I, Hinton GE. Imagenet classification with deep convolutional neural networks. In: Proceedings of the 25th international conference on neural information processing systems. 2012; 1. p. 1097-1105.

[3] Narin A, Ceren K, Ziynet P. Automatic detection of coronavirus disease (covid-19) using X-ray images and deep convolutional neural networks. arXiv:2003.10849; 2020.

[4] Hemdan, E.E.D.; Shouman, M.A.; Karar, M.E. Covidxnet: A framework of deep learning classifiers to diagnose covid-19 in X-rayimages.arXiv2020, arXiv:2003.11055

[5], Asnaoui K, Chawki Y, Idri A, et al. Automated methods for detection and classification pneumonia based on X-ray images using deep learning. 2020, arXiv:2003.14363.

[6] Brunese L, Mercaldo F, Reginelli A, Santone A. Explainable Deep Learning for Pulmonary Disease and Coronavirus COVID-19 Detection from X-rays. Comput Methods Programs Biomed. 2020 Nov;196:105608. doi: 10.1016/j.cmpb.2020.105608. Epub 2020 Jun 20. PMID: 32599338; PMCID: PMC7831868. 
[7] Hu, Yifan and Y. Zheng. "A GLCM Embedded CNN Strategy for Computer-aided Diagnosis in Intracerebral Hemorrhage." ArXiv abs/1906.02040 (2019): n. pag.

[8] Dai W, Zhang H, Yu J, et al. CT Imaging and Differential Diagnosis of COVID-19. Canadian Association of Radiologists Journal. 2020;71(2):195-200. doi:10.1177/0846537120913033

[9] Nasr, G.E. \& Badr, E. \& Joun, C.. (2002). Cross Entropy Error Function in Neural Networks: Forecasting Gasoline Demand.. 381-384.
[10] Irmak, E. COVID-19 disease severity assessment using CNN model. IET Image Process. 2021; 15: 1814- 1824. https://doi.org/10.1049/ipr2.12153

[11] Carvalho, A.R., et al.: COVID-19 chest computed tomography to stratify severity and disease extension by artificial neural network computer-aided diagnosis. Front. Med. 7(12), 1-11 (2020) 


\title{
КЛАССИФИКАЦИЯ ПОРАЖЕНИЯ ЛЕГКИХ ПРИ СОVID-19 НА ОСНОВЕ ТЕКСТУРНЫХ ПРИЗНАКОВ И СВЕРТОЧНОЙ НЕЙРОННОЙ СЕТИ
}

\author{
Давидько О.Б. ${ }^{1}$, аспирант \\ o.davydko@kpi.ua \\ Ладик A. ${ }^{1}{ }^{1}$, бакалавр \\ artur.ladik01@gmail.com \\ Максименко В.Б. ${ }^{1}$, Д.М.Н., проф. \\ maksymenko.vitaliy@gmail.com \\ Линник Н. И. ${ }^{2}$, д.м.Н., в.Н.с \\ linnyk@ifp.kiev.ua \\ Павлов А.В. ${ }^{1}$, к.т.н., ст.П. \\ cheshirelk@gmail.com \\ Настенко Е. $\boldsymbol{A .}^{1}{ }^{1}$, к.т.н., д.б.н., проф. \\ nastenko.e@gmail.com
}

\author{
${ }^{1}$ Национальный технический университет Украины \\ «Киевский политехнический институт имени Игоря Сикорского» \\ Киев ,Украина \\ ${ }^{2}$ ДУ «Национальный интститут фтизиатрии и пульмонологии \\ им. Ф.Г. Яновского НАМН Украины» \\ Киев ,Украина
}

Peферат - Проблематика. Определение структуры поражения легочной ткани больных COVID-19 по типовым признакам «матовое стекло», «булыжная мостовая», «консолидация» является важной составляющей обоснования диагностики и состава лечебных мероприятий на текущий момент терапии пациента. Наиболее распространенным средством определения стадии и типа поражения дыхательных путей является анализ рентген изображений и компьютерной томографии (КТ). Поскольку особенностью вирусной пневмонии SARS-CoV-2 является быстрый переход от легких стадий к тяжелым с развитием цитокинового шторма и распростронения инфекции в артериальный кровоток, то надежный и быстрый анализ КТ изображений легких пациента является залогом принятия своевременных лечебных мероприятий. В данной работе рассматриваются возможности применения средств искусственного интеллекта для решения задачи классификации поражений легких при заболевании COVID-19.

Цель. Целью работы является создание классификационной системы типа поражений легких при COVID-19 по типу «матовое стекло», «булыжная мостовая», «консолидация» на основе сверточной нейронной сети CNN и текстурных признаков, источником которых является матрица смежности GLCM при различных значениях углов направления анализа

Методика реализации. Поскольку основой различий разных типов поражения легочной ткани на КТ изображениях являються различия в их текстурных характеристиках, то в основу пространства признаков классификационной системы заложим элементы гистограмм на основе матриц смежности областей интереса КТ изображений легких. В связи с высокими качествами преобразования пространства признаков к потребностям задач классификации сверточными слоями сети, средством построения классификатора предлагается применить сверточную нейронную сеть. Для обучения системы ГУ "« Национальный институт фтизиатрии и пульмонологии им. Ф. Яновского АМН Украины »было предоставлено 8272 КТ изображений от 20 пациентов с масками изображений, на которых выделены зоны интереса с обозначенными типами поражений легких. Была построена модель семи-слойной сверточной нейронной сети: с четырьмя сверточными слоями, после первых трех из которых идут субдискретизирующих слоя. На вход сверточной нейронной сети одновременно подаются текстурные признаки двух GLCM, которые были получены из сегментированных КТ изображений под разными углами. В качестве функции потерь была использована NLLLOSS. Слой активации Softmax определяет результат задачи классификации.

Результаты исследования. Построена сверточная нейронная сеть на тестовой выборке из 472 изображений имеет общую точность классификации в 83\%, на классах «матовое стекло» - 90,1\%, «булыжная мостовая» - 70,5\%, «консолидация» - 54,2\% и на рабочей выборке из 4714 ROI изображений имеет общую точность в 98\%, на классах «матовое стекло»- $98,6 \%$, «булыжная мостовая» - 96,8\%, «консолидация» - 95,4\%

Bblводы. В работе получена модель с высокой эффективностью классификации типа поражений легких при COVID-19. Классификатор построен на основе сверточной нейронной сети и признаков текстур, источником которых являются матрицы смежности областей интереса КТ изображений легких.

Ключевые слова - GLCM, матрицы смежности уровней серого тона, зона интереса, компьютерная томография, COVID19, сверточная нейронная сеть, поражение легких, матовое стекло, булыжная мостовая, консолидация 


\title{
CLASSIFICATION OF LUNG LESION DURING COVID-19 BY TEXTURE FEATURES AND CONVOLUTIONAL NEURAL NETWORK
}

\author{
Davydko O.B. ${ }^{1}$, Graduate student. \\ o.davydko@kpi.ua \\ Ladik A.O. ${ }^{1}$, Bachelor \\ artur.ladik01@gmail.com \\ Maksimenko $V . B .{ }^{1}$ \\ Doctor of Medical Sciences,Professor \\ maksymenko.vitaliy@gmail.com \\ Lynnyk M.I ${ }^{2}$ Doctor of Med. Sciences, Lead. Res. \\ linnyk@ifp.kiev.ua \\ Pavlov O.V. ${ }^{1}$, Ph.D.,Sen.teach. \\ cheshirelk@gmail.com \\ Nastenko Ye.A. ${ }^{1}$, \\ Doctor of Biological Sciences, \\ Ph.D. of Technical Sciences, Professor, \\ nastenko.e@gmail.com \\ ${ }^{1}$ National Technical University of Ukraine \\ "Igor Sikorsky Kyiv Polytechnic Institute" \\ Kiev, Ukraine \\ ${ }^{2}$ SI "National institute of phthisiology and pulmonology \\ named after F. G. Yanovskiy NAMS of Ukraine" \\ Kiev, Ukraine
}

Abstract - Background. Determination of the structure of lung tissue lesions of patients with COVID-19 to the types of " Ground-glass opacity ", "crazy-paving", "consolidation" is an important component of substantiating the specific composition of therapeutic measures at the current moment of patient therapy. The most common means of determining the stage and type of airway lesions is through $\mathrm{x}$ ray images and computed tomography (CT) scans. Since a feature of SARS-CoV-2 viral pneumonia is a rapid transition from mild to severe stages with the addition of the consequences of a cytokine storm and the breakthrough of infection into the arterial bloodstream, a reliable and fast analysis of CT images of the patient's lungs is the key for timely taking treatment measures. This paper discusses the possibility of using artificial intelligence for solving the problem of classifying lung lesions in COVID-19 disease.

Objective. The aim of the work is to create a classification system of lung lesions type during COVID-19 by the types of " Groundglass opacity ", "crazy-paving", "consolidation" based on the CNN convolutional neural network and textural features, the source of which are GLCM adjacency matrixs with different values of the angles of the direction of analysis.

Methods. Since the differences in different types of lung tissue lesions on CT images are based on differences of their textural characteristics, the basis of the space of signs of the classification system will be the elements of histograms based on the adjacency matrices of regions of interest for CT images of the lungs. Due to the high quality of the transformation of the feature space to the needs of classification problems by convolutional layers of the network, it is proposed to use a convolutional neural network by means of constructing a classifier. To train the system of the State Institution "F. Yanovsky National Institute of Phthisiology and Pulmonology of the Academy of Medical Sciences of Ukraine", 8272 CT slices from 20 patients with image masks were provided, on which zones of interest with indicated types of lung lesions were identified. A model of a seven-layer convolutional neural network was built: with four convolutional layers, after the first three of which come pooling layers. To the input of a convolutional neural network, texture features of two GLCMs, which were obtained from segmented CT images at different angles, are simultaneously fed. NLLLOSS was used as a loss function. The Softmax activation layer determines the result of the classification task.

Results. A convolutional neural network has been built on a test set of 472 images and has an overall classification accuracy of $83 \%$, for " Ground-glass opacity " classes - 90.1\%, "crazy-paving" - 70.5\%, "consolidation" - 54.2\%, and a working sample of 4714 ROI images has an overall accuracy of 98\%, for " Ground-glass opacity “- 98.6\%, "Crazy-paving" - 96.8\%, "consolidation" - 95.4\%

Conclusions. A model with a high efficiency of classification of the type of lung lesions during COVID-19 has been obtained. The classifier is built on the basis of a convolutional neural network and texture features, the source of which are the GLCM matrices of regions of interest for $\mathrm{CT}$ images of the lungs.

Keywords- GLCM, Grey-Level Co-Occurrence Matrix, Region of Interest, ROI, computer tomography, COVID-19, Convolutional Neural Network, lung lesion, ground glass opacity, crazy-paving 